Jurnal Pemberdayaan: Publikasi Hasil Pengabdian kepada Masyarakat

Vol. 2, No. 2, Agustus 2018, Hal. 297-304

ISSN: 2088 4559; e-ISSN: XXXX-XXXX

DOI:

\title{
PEMBERDAYAAN WARGA MELALUI USAHA PEMBUATAN BESEK DI GUMAWANG GUNUNG KIDUL
}

\author{
Reni Dwi Astuti, Tri Budiyanto, Muhammad Faishal \\ Universitas Ahmad Dahlan, Yogyakarta \\ reni_dwiastuti@ie.uad.ac.id
}

\begin{abstract}
ABSTRAK
Dusun Gumawang merupakan wilayah yang kaya akan bambu, sehingga banyak pengrajin bambu di daerah tersebut. Akan tetapi kapasitas produksi masih rendah sehingga tidak dapat memenuhi permintaan pasar. Hal ini disebabkan karena jumlah pengrajin sedikit (lebihkurang 10 orang) dan kurangnya tenaga kerja yang melakukan proses pengiratan bambu. Selain itu kualitas produk rendah, karena mudah rusak (berjamur) karena kandungan air pada produk terlalu tinggi, khususnya di musim hujan. Masalah lain yang dijumpai adalah sistem kerja yang tidak ergonomis serta tidak ada pembukuan keuangan. Untuk itu ditawarkan solusi berupa pelatihan bagi warga Gumawang sehingga menambah jumlah pengrajin, penggunaan teknologi pengeringan produk untuk mengurangi kadar air supaya produk awet, penyuluhan tentang ergonomi, dan pelatihan tentang manajemen keuangan. Manfaat akhir dari program pengabdian adalah meningkatan pendapatan pengrajin maupun warga pada umumnya.
\end{abstract}

Kata kunci: bambu, pengiratan, besek, penganyaman

\begin{abstract}
Gumawang is an area with lots of bamboo, so many bamboo craftsmen in the area. However, production capacity is still low and cannot meet market demand. This is due to the small number of craftsmen (approximately 10 people) and the low number of workers who carry out the bamboo process. In addition, product quality is low, because it is easily damaged (moldy) caused by the water content in the product is too high, especially in the rainy season. Another problem encountered is a non-ergonomic work system and no financial accounting. To solve the problem, a solution was offered in the form of training for Gumawang residents to increase the number of craftsmen, use of product drying technology to reduce water content so that products last longer, counseling on ergonomics, and training on financial management. Another benefit of the service program is increasing the income of craftsmen and residents in general.
\end{abstract}

Keywords: bamboo, craftsmen, non-ergonomic, financial management 


\section{PENDAHULUAN}

Dusun Gumawang, Patuk, Kabupaten Gunung Kidul yang terletak di provinsi Daerah Istimewa Yogyakarta (DIY) memiliki banyak potensi alam yang dapat dimanfaatkan. Sehingga, muncul banyak industri kecil yang bergerak dalam berbagai bidang. Salah satunya adalah industri kecil kerajinan bambu yang memanfaatkan bahan baku bambu dari daerah tersebut. Bahan baku yang melimpah di Dusun Gumawang merupakan peluang bagi masyarakat sekitar untuk memperoleh bahan baku bambu dengan mudah.

Pada awalnya masyarakat sekitar hanya menjual bahan baku bambu mentah langsung kepada pengrajin di luar Dusun Gumawang. Kondisi tersebut membuat perekonomian warga belum dapat ditingkatkan karena keuntungan dari penjualan bahan baku relatif kecil jika dibandingkan penjualan bambu olahan atau kerajinan bambu. Untuk itu masyarakat Dusun Gumawang memulai usaha kerajinan bambu untuk meningkatkan nilai tambah penjualan bambu.

Berdasarkan hasil analisis di lapangan dan hasil diskusi dengan Ketua paguyuban pengrajin bambu, yaitu Bapak Sugito Rejo (Mitra 1) dan Bapak Tugiyo (Mitra 2) serta anggota, tantangan yang dihadapi para pengrajin bambu ini cukup banyak, sehingga perlu pendampingan. Wajar apabila hasil produksi kerajinan bambu masyarakat Dusun Gumawang dirasa masih kurang dapat bersaing dengan produk kerajinan bambu lainnya. Hal ini terutama berkaitan dengan kapasitas dan kualitas produk. Tingginya permintaan besek tidak mampu diserap oleh pengrajin. Sedangkan untuk masalah kualitas dipengaruhi oleh proses produksi yang dilakukan. Sebagai contoh, iratan bambu yang dibuat memiliki tingkat ketebalan dan lebar yang berbeda-beda sehingga menyebabkan produk yang dihasilkan menjadi kurang baik bentuknya dan kurang nyaman saat dianyam. Hal ini disebabkan karena proses produksi iratan bambu masih dilakukan secara tradisional sehingga output tidak standar. Jumlah pengirat juga sangat sedikit, sehingga tidak memenuhi permintaan pasar. Saat menganyam besek yang merupakan produk dengan permintaan terbanyak, pengrajin tidak menggunakan standar ukuran produk, sehingga ukuran tidak seragam. Proses menganyam juga tidak ada alat bantu untuk 'memegang' iratan bambu, sehingga 
pengrajin harus menaham iratan bambu dengan kaki, sementara kedua tangan untuk menganyam. Hal ini menyebabkan proses menganyam menjadi lama.

Hal lain yang dihadapi mitra adalah keawetan hasil kerajinan yang dibuat, khususnya besek, yaitu mudah berjamur. Penyebab utama masalah ini adalah tingginya kadar air dalam produk. Teknik pengawetan yang pernah dicoba oleh pengrajin adalah dengan penggunaan bahan kimia. Akan tetapi, penggunaan bahan kimia ini tidak aman untuk produk besek, karena digunakan untuk wadah makanan, sehingga tidak dilakukan lagi. Teknik pengawetan bambu yang alami diantaranya adalah dengan pengasapan dan pemanggangan (http://vedcmalang.com/pppptkboemlg/index.php/departemen-bangunan-30/1050har ). Teknik pemanggangan bisa dicoba untuk kasus di Gumawang.

Dari sisi kesehatan dan keselamatan kerja, proses penipisan bambu atau proses irat bambu yang dilakukan saat ini masih hanya menggunakan pisau secara manual, sehingga sangat berpotensi menimbulkan terjadinya kecelakaan kerja teririsnya jari tangan oleh pisau maupun bilah bambu yang sedang diirat. Selain itu posisi kerja pengrajin bagian anyaman sangat berpotensi menimbulkan keluhan Moskuloskeletal Disorder (MSDs) yaitu keluhan-keluhan kelelahan pada sistem otot pada tubuh pekerja yang pada kelanjutannya dapat menimbulkan cedera permanen (https://merulalia.wordpress.com/2010/08/30/msds/).

\section{METODE}

Metode pengabdian yang diterapkan meliputi penyuluhan, pelatihan dan pemberian alat. Program dilakukan dalam beberapa hari dan saat ini masih dilanjurkan dengan pendampingan

Tabel 1 memperlihatkan solusi dan target luaran yang dilakukan dalam program pengabdian.

Tabel 1. Solusi dan target luaran Program Kemitraan Masyarakat Dusun Gumawang, Desa Putat, Kecamatan Patuk, Gunung Kidul

\begin{tabular}{|l|l|l|l|l|}
\hline No & $\begin{array}{l}\text { Permasalah- } \\
\text { an umum }\end{array}$ & Prioritas Permasalahan & Solusi & Target luaran \\
\hline 1 & $\begin{array}{l}\text { Bidang } \\
\text { produksi }\end{array}$ & $\begin{array}{l}\text { Posisi kerja yang tidak } \\
\text { ergonomis }\end{array}$ & $\begin{array}{l}\text { Memberikan } \\
\text { penyuluhan dan dan }\end{array}$ & $\begin{array}{l}\text { Metode ritas kerja } \\
\text { fasilitas }\end{array}$ \\
\hline
\end{tabular}




\begin{tabular}{|c|c|c|c|c|}
\hline & & & $\begin{array}{lll}\text { pelatihan tata } & \text { cara } \\
\text { kerja } & & \text { yang } \\
\text { ergonomis } & & \\
\end{array}$ & $\begin{array}{l}\text { yang } \\
\text { ergonomis }\end{array}$ \\
\hline & & $\begin{array}{l}\text { Kerajinan bambu mudah } \\
\text { terserang jamur }\end{array}$ & $\begin{array}{l}\text { Penggunaan } \\
\text { teknologi tepat guna } \\
\text { berupa oven untuk } \\
\text { mengurangi kadar } \\
\text { air dari bambu } \\
\text { sehingga tidak } \\
\text { mudah berjamur }\end{array}$ & $\begin{array}{l}\text { Kerajinan } \\
\text { lebih awet }\end{array}$ \\
\hline & & $\begin{array}{l}\text { Kualitas hasil iratan } \\
\text { bambu tidak seragam }\end{array}$ & $\begin{array}{l}\text { Pelatihan mengirat } \\
\text { bambu }\end{array}$ & $\begin{array}{l}\text { Hasil iratan } \\
\text { seragam }\end{array}$ \\
\hline 2 & $\begin{array}{l}\text { Bidang } \\
\text { manajemen }\end{array}$ & Manajemen keuangan & $\begin{array}{l}\text { Melakukan pelatihan } \\
\text { pengelolaan } \\
\text { keuangan }\end{array}$ & $\begin{array}{l}\text { Terdapat } \\
\text { pembukuan } \\
\text { keuangan }\end{array}$ \\
\hline
\end{tabular}

\section{HASIL, PEMBAHASAN, DAN DAMPAK}

a. Penyuluhan tentang sistem kerja yang ergonomis

Pelatihan tentang ergonomi diselenggarakan mengingat banyak pengrajin besek yang tidak memperhatikan posisi kerja dengan baik saat bekerja. Hal ini akan mengakibatkan cepat lelah saat bekerja. Selain itu dalam jangka panjang akan berpotensi mengakibatkan penyakit, khususnya yang menyerang tulang belakang. Gambar 1 menunjukkan saat penyuluhan tentang posisi kerja yang ergonomis. Dari penyuluhan ini diharapkan para pengrajin lebih memperhatikan posisi kerja saat mengirat maupun menganyam besek, sehingga terhindar dari kelelahan dan penyakit akibat kerja dalam jangka panjang.

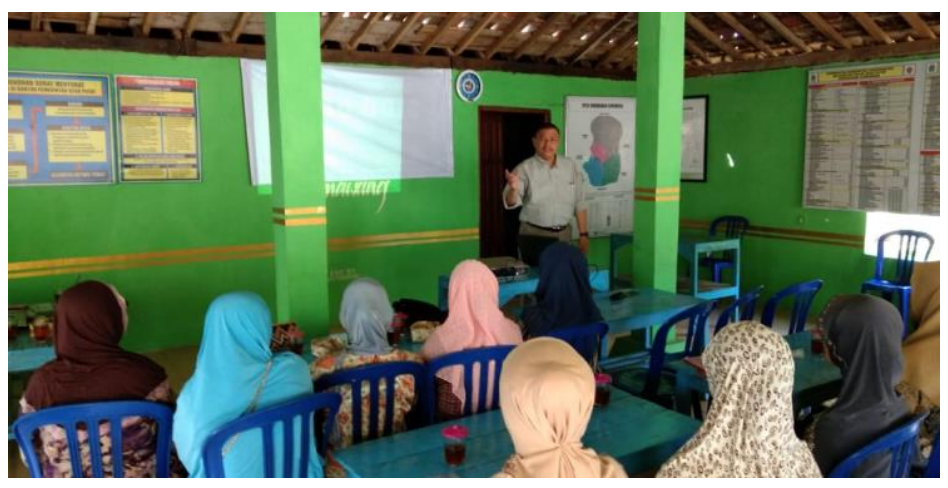

Gambar 1. Penyuluhan tentang ergonomi

b. Penyuluhan tentang pengelolaan keuangan

Berdasarkan observasi dan wawancara kepada salah seorang pengrajin besek, didapati informasi bahwa para pengrajin umumnya tidak melakukan pengaturan keuangaan. Mereka bahkan belum pernah menghitung apakah usaha 
yang dijalankan memberikan keuntungan atau tidak. Oleh karena itu diberikan pelatihan tentang pembukuan keuangan dan penentuan harga pokok produksi. Gambar 2 adalah pelaksanaan penyuluhan tentang keuangan.

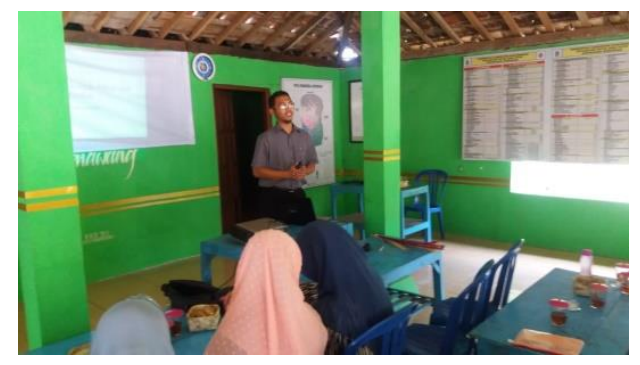

Gambar 2. Penyuluhan tentang keuangan

c. Pelatihan mengirat dan menganyam besek

Pelatihan mengirat dan menganyam bambu diikuti oleh kurang lebih 20 peserta. Dalam pelatihan tersebut sekaligus diberikan motivasi oleh tim untuk terus mencoba memroduksi besek karena permintaan cukup tinggi dan selama ini sering kali tidak terpenuhi. Gambar 3 dan 4 adalah proses pelatihan mengirat dan menganyam besek.

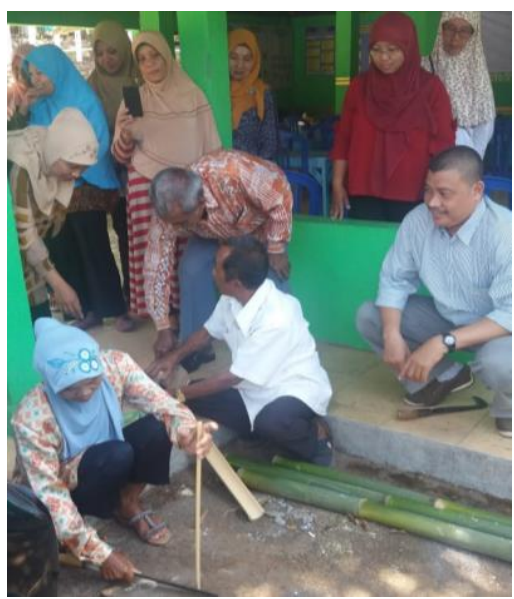

Gambar 3. Pelatihan mengirat bambu

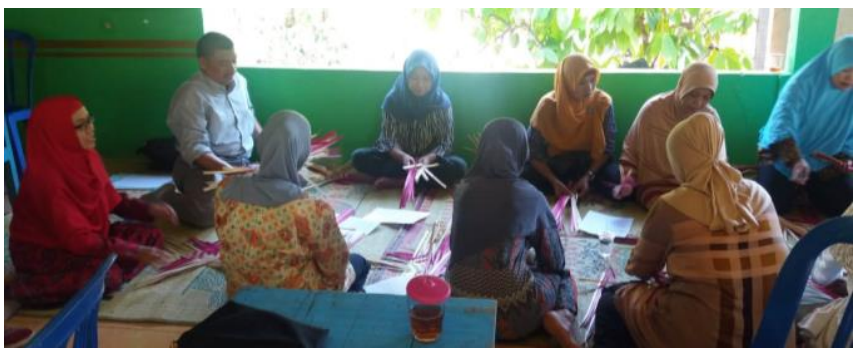

Gambar 4. Pelatihan menganyam besek

d. Pemberian oven

Pemberdayaan Warga Melalui Usaha (Reni Dwi A.)| 301 
Persoalan lain yang dihadapi warga adalah kondisi bambu yang lembab sehingga sangat mudah berjamur. Teknik yang paling sederhana dalam pengawetan bambu adalah dengan mengurangi kadar air, misalnya dengan melakukan pengasapan atau penjemuran. Selama ini warga melakukan penjemuran besek untuk mencegah kerusakannya. Akan tetapi teknik ini mengalami kendala saat musim hujan, sehingga dibutuhkan alat bantu untuk mengeringkan besek. Di sini tim pengabdian masyarakat membantu dengan menyediakan oven. Gambar 5 adalah acara serah terima oven kepada ketua paguyuban pengrajin besek.

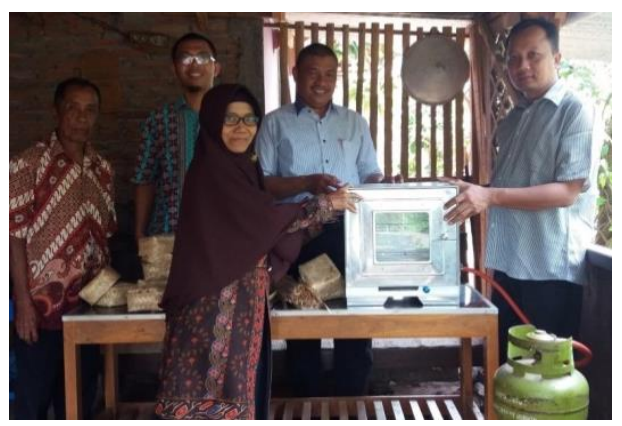

Gambar 5. Penyerahan oven kepada pengrajin besek

Kapasitas oven ini mencapai 32 lembar besek kecil atau 16 tangkep besek kecil. Bahan bakar yang digunakan adalah gas. Bahan bakar yang digunakan adalah gas. Untuk sekali proses pengeringan dibutuhkan waktu hanya 2-3 menit. Dari sisi waktu, jelas lebih singkat untuk mengeringkan bambu dibandingkan jika harus dijemur. Biaya pengeringan dengan oven juga tidak terlalu tinggi karena hanya butuh waktu singkat untuk mengeringkannya. Gambar 6. adalah proses uji coba penggunaan oven.

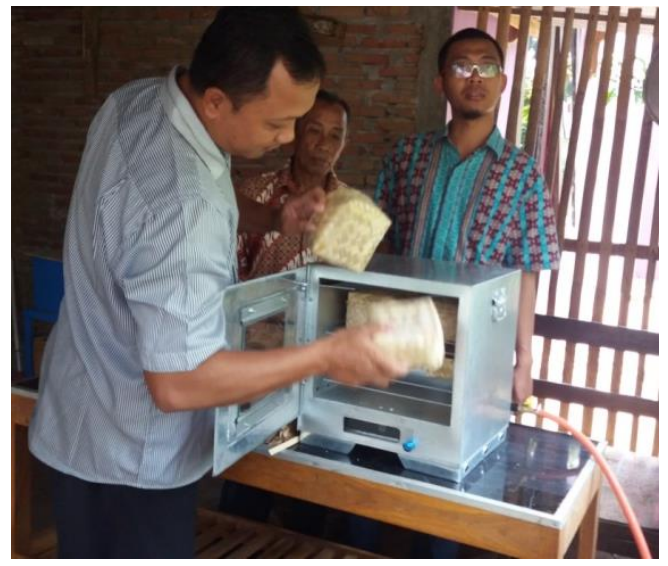

Gambar 6. Uji coba penggunaan oven 
Berdasarkan pengamatan dilapangan, mayoritas pekerjaan masyarakat gumawang yang laki-laki adalah seorang buruh petani dengan tingkat ekonomi menengah ke bawah, sedangkan untuk ibu-ibu sebagian besar merupakan ibu rumah tangga. Program pelatihan yang sudah diselenggarakan ini diharapkan mampu membantu menambah pendapatan keluarga sehingga meningkatkan tingkat ekonomi masyarakat dengan sasaran peserta adalah ibu-ibu rumah tangga Dusun Gumawang. Setelah program pelatihan ini dijalankan, dilakukan pendampingan oleh trainer kepada para peserta. Hasil dari pelatihan dan pendampingan cukup memuaskan yaitu hanya 3 orang dari total peserta 23 orang yang berhenti mengaplikasikan hasil pelatihan.

Berdasarkan wawancara dengan beberapa peserta yang telah mengikuti pelatihan, mereka puas dan senang dengan tambahan kegiatan baru berupa pembuatan besek yang dapat memberikan pendapatan tambahan bagi keluarga. Kegiatan pembuatan besek ini dilakukan disela-sela waktu kosong mereka sebagai ibu rumah tangga, dan hasilnya mereka dapat membuat besek sebanyak 50 - 100 pasang besek per minggu dan kedepannya dengan berjalannya waktu akan meningkatkan ketrampilan mereka sehingga menambah jumlah produksinya. Sebagai pemula yang baru menekuni pembuatan besek beberapa bulan mereka sangat puas dengan hasil tersebut. Penghasilan tambahan yang dapat mereka peroleh antara Rp 50.000,00 - Rp 90.000,00 per minggu. Dampak lain yang dirasakan dari pelatihan ini adalah pemenuhan produksi sudah mendekati permintaan pasar besek. Sebelum diadakan pelatihan, dari 1000 unit permintaan per minggu hanya mampu memenuhi sekitar 600 unit. Setelah pelatihan permintaan besek dapat terpenuhi hingga sekitar 900 unit.

\section{SIMPULAN}

Penyuluhan tentang ergonomi dan pengelolaan keuangan dapat meningkatkan pemahaman warga sehingga mereka lebih memperhatikan kedua aspek tersebut. Pelatihan mengirat bambu dan menganyam besek dapat meningkatkan pendapatan warga. Pengovenan besek mampu menjaga produk tetap awet. Besek tidak mudah rusak karena jamur. 


\section{DAFTAR PUSTAKA}

Anonim, 2010. Musculoskeletal disorder. https://merulalia.wordpress.com/2010/08/30/msds/. Diakses pada 20 Juni 2017.

Hartiyono. Cara Pengawetan Bambu, http://vedcmalang.com/pppptkboemlg/index.php/departemen-bangunan30/1050-har. diakses pada 20 Juni 2017

Wahyono, Ari, 2013. Mesin oven untuk tusuk sate dan tusuk gigi.

http://tokotusuksate.blogspot.co.id/2013/01/mesin-oven-untuk-tusuk-satedan-tusuk.html. diakses pada 18 Juni 2017 